\title{
Rubrication Patterns in Two Old Nubian Manuscripts from Serra East
}

\author{
Vincent W.J. van Gerven OeI, Alexandros Tsakos
}

\begin{abstract}
The present paper analyses the rubrication patterns in two Old Nubian manuscripts (known under the sigla St and SC) both originally intended for deposition at the Jesus Church in Serra East. Through a comparison with rubrication patterns in other Old Nubian manuscripts, the authors argue that the rubricated phrases in St and SC show an internal coherence that could be interpreted as a 'second voice' in a 'polyphonic' text.
\end{abstract}

Keywords: Old Nubian, rubrication, Biblical citations, Serra East, polyphony, manuscripts

Vincent W.J. van Gerven Oei, independent researcher, The Hague; vincent@vangervenoei.com; (iD) $0000-0003-1637-4261$

Alexandros Tsakos, University of Bergen, Bergen; alexandros.tsakos@uib.no; (D) 0000-0001-8254-0964

In 1906, the German Coptologist Karl Schmidt purchased in Egypt, among other manuscripts, a small codex, which was subsequently registered as Berlin, Kgl. Bibl. MS. Orient. Quart 1020. It was Schmidt himself who first suggested that the language of this manuscript was 'Old Nubian'. ${ }^{1}$ The first person, however, to decipher longer parts of the text was the Egyptologist Heinrich Schäfer, director of the Egyptian Museum in Berlin between 1914 and 1935. Schäfer introduced the language to the British Egyptologist Francis Llewellyn Griffith, who pioneered the systematic study of both the Meroitic and Old Nubian languages. Griffith and Schäffer made the first transcript of the text and identified it as mainly a discourse of Christ with his apostles before the Ascension, concerning the Cross, followed by a hymn to the Cross. ${ }^{2}$ The two works, named by Griffith and Schäffer as the Stauros-Text, were followed by a colophon stating that it was dedicated before Jesus of ceppen matтo 'East Serra'.

\footnotetext{
Schäfer, Schmidt 1906: 775.

Griffith 1913: 41-42.

Griffith 1913: 4.
} 
Seventy years later, Gerald Michael Browne, who worked on almost the entire corpus of Old Nubian texts and produced both an Old Nubian Grammar ${ }^{4}$ and an Old Nubian Dictionary, ${ }^{5}$ published a revised edition of the Stauros-Text. ${ }^{6}$ The reason for returning to this manuscript was the discovery of two codices containing elements of the Stauros-Text. ${ }^{7}$ At Serra East, the Nubian Expedition of the Oriental Institute of Chicago had discovered a new codex preserving the longest known Old Nubian text, namely the pseudo-Chrysostomian Sermon on the venerable Cross, which partially overlapped with the hymn to the Cross at the end of the Stauros-Text. ${ }^{8}$ The same expedition also uncovered a small codex in Sahidic Coptic at Qasr el-Wizz, containing two works, the first of which is identical to the first part in the Stauros-Text. ${ }^{9}$ Thus, there appears a tradition in Nubia of combining in a single codex two works relating to the Cross, probably from a common pool of texts, as is shown by the overlaps between the three above-mentioned witnesses.

It is important to note that the colophon of the Stauros-Text is remarkably similar to the one of the Sermon on the venerable Cross, both mentioning the deposition of the codex in the Jesus Church of Serra East. However, only the latter received the name Serra East codex. Such literary creations undoubtedly served to praise the donor in front of the priesthood and God, and therefore their material manifestations are of primal importance for achieving this goal. In other words, they can be expected to be objects of prestige, careful in offering the best possible version of what a luxurious codex would be expected to offer in a given cultural context, and, if possible, even excelling in the beauty and richness of the impression they would make. Both the Stauros-Text and the Serra East codex definitely achieve this task, as exemplified by the skilful and elegant handwritings, the well-planned layout of the nicely decorated pages, and in the case of the Stauros-Text, last but not least, the colourful illustration of, most probably, the donor of the work. ${ }^{10}$

The use of colour in the text itself is an important element in attaining a high degree of quality in a Nubian manuscript. The most common practice of colour decoration is called rubrication and consists of the addition of red colour for special sections of a text, like the titles and the colophons, or for particular words and phrases that the scribe wished to highlight, primarily the nomina sacra. The tradition goes back to hieroglyphic texts ${ }^{11}$ and it becomes a diagnostic element of Christian practice in texts from the Nile region to such an extent that when at the beginning of the nineteenth century the 'Egyptologist' Henry Salt traveled to Ethiopia, he did not manage to get the locals interested in printed Ethiopic psalters that he had brought along to exchange with their manuscripts, as they found fault $[\ldots]$ with the sacred names because they were not done in red ink. ${ }^{12}$

\footnotetext{
${ }^{4}$ Browne 2002.

${ }^{5}$ Browne 1996.

${ }^{6}$ Browne 1983.

Browne 1983: 75-76.

${ }^{8}$ Browne 1984.

${ }^{9}$ Hubai 2009.

${ }^{10}$ Woźniak 2018.

${ }^{11}$ E.g. Parkinson, Quirke 1995: 44-45.

12 Quoted in Russell 1985: 304-305.
} 
In the present paper, we will first see how the use of especially red ink underlines this high artistic quality and adds symbolic value to Nubian manuscripts. And second, we will investigate various explanations for the choices Nubian scribes had in rubricating parts of their work. Finally, although until now no particular system for the particularities noted (for example, selective rubrication of names of divine beings) has been detected, we will propose paths to identifying such systems, based on two of the four complete literary works extant in Old Nubian: the Serra East codex (SC) and the Stauros-Text (St).

\section{COLOUR USAGE IN THE NUBIAN MANUSCRIPT TRADITION}

In the Mediterranean basin, black and red have been the primary colours used in the production of codices, and later books. The time span of this scribal custom covers all periods from proto-history (e.g. use of red colour in hieroglyphic texts) to modern times (e.g. printed editions of liturgical books for use in churches). The large number of examples and their spread across chronological, geographical, cultural, and linguistic frontiers have kept their exhaustive collection and systematic analysis a desideratum. In anticipation of such a project, it is worthwhile turning our attention to the particular case study of manuscripts from Christian Nubia, both because the corpus of known texts is relatively small and because it offers some very interesting insights into the phenomenon examined here.

Literacy in medieval Nubia is expressed multilingually. ${ }^{13}$ Apart from Old Nubian, Greek and Coptic (primarily Sahidic, but also Bohairic) are widely used. Arabic also appears, while there have been instances of the use of Ottoman Turkish, Syriac, and Latin as well. All the three most popular languages have been used to write both literary and documentary texts and have been attested on manuscripts made of paper, parchment, leather, and papyrus. All the texts on soft carriers are written with black or brown ink. Occasionally, however, an additional colour, red, is employed.

As stated above, the colour red is used primarily in order to mark special sections in a manuscript, like incipits and explicits, head chapters and colophons, or to highlight important words like nomina sacra, and to decorate individual signs (letters or punctuation). There are also attested a couple of instances where the entire text has been rubricated, possibly underlining the significance of its content and/or purpose. ${ }^{14}$

These customs appear across the languages used in Christian Nubia, but some discrepancies have been discovered that offer points of reference for further investigation. For example, it has been observed that decorating the lobes of the letter $\phi$ with red, which is a very common phenomenon in Nubian literacy, occurs exclusively in texts of a religious character. ${ }^{15}$ Nevertheless, it would be wrong to assume that manuscripts with religious texts were seen by Nubians more highly than for example manuscripts of a documentary

13 Ochała 2014.

14 See, for example: Tsakos forthcoming; Van Gerven Oei, Łajtar 2019: 92-96. Interestingly, both texts appear to refer to the cult of the Archangel Michael, which was very popular in Christian Nubia (see: Gilhus, Tsakos, Wright (Eds) 2019: 76-107).

15 Tsakos 2016. 
character, since royal decrees and other legally binding texts had great significance in Nubian society, albeit apparently of a different order than religious manuscripts. Given the absence of the usage of the red colour in documentary texts from medieval Nubia, we suggest that for the Nubians, the colour red added symbolic value of a religious nature to the manuscripts in which it was used.

These observations hold especially for Old Nubian manuscripts, for which, on the one hand, we can be quite certain that the creators were Nubians representing the intellectual choices of local society, while, on the other hand, Old Nubian manuscripts illustrate clearly what can be seen as not more than tendencies in manuscripts in Greek and Coptic. ${ }^{16}$ Nevertheless, the study of manuscript decoration ${ }^{17}$ and the derivation of the 'Nubiantype majuscules' common in Nubian manuscripts from the Coptic oncial penchée,$^{18}$ have underlined the initial dependence of the Old Nubian manuscript tradition on centers of Egyptian, especially Sahidic literacy.

In any case, once adopted by the Nubians, this system of decoration with red ink seems to have been developed to its maximum potential: it appears, among others, in rubrics and interpunction (e.g. Old Nubian Lectionary = Kgl. Bibl. MS. Or. Quart 1019; $D B M N T$ 687), incipits (e.g. Miracle of Saint Menas and the (pseudo-)Nicene canons $=$ BL Or. 6805; DBMNT 713), and to mark the names of holy figures (e.g. The Attiri Book of Michael = Sudan National Museum SNM 23045; DBMNT 714). There are, however, two manuscripts that stand out because of their high quality and some peculiar aberrations from this general categorisation.

\section{RUBRICATION IN SC AND ST}

Like other Old Nubian manuscripts, the pseudo-Chrysostomian homily Sermon on the venerable Cross (traditionally known under the siglum SC; DBMNT 1385$)^{19}$ is written in a neat and regular Nubian-type majuscule. Browne offers an overview of the rubrication, ${ }^{20}$ which includes the title and the marginal note, lobes of the $\phi$, and interpunction. He also provides a list of 'certain religious names and words', which, however, do not appear consistently rubricated. Moreover, there are several instances in which additional words before or after 'certain religious names and words' are rubricated. Keeping in mind that the effort put into the manuscript and its value as a devotional object, which suggest a careful handling of every aspect of the text, including the rubrication, it appears reasonable to us to consider the possibility that there is an underlying pattern to the usage of colour.

${ }^{16}$ For example, the paleographic customs examined here can only be observed in a small subset of the manuscripts in Sahidic Coptic unearthed at the monastery of Qasr el-Wizz. The reasons may be linked with the suggestion that many were imports from Egypt (see: Tsakos forthcoming).

17 Tsakos 2016.

18 Boud'hors 1997. Further influences upon the formation of the Old Nubian paleographic styles can be found among scripts used at Sinai and at Fayyum, but their study is still in progress.

19 For a detailed treatment of SC, see: Van Gerven Oei, Tsakos forthcoming.

20 Browne 1984: 19-20. 
Besides the incipit and marginal note, which are fully in red, there are two sections in SC with extensive rubrication of a single keyword. In SC 14.4-16.20, the 'Hymn on the Cross', the word çтаүрос $\bar{\lambda}$ 'cross' is consistently rubricated. The same holds for the

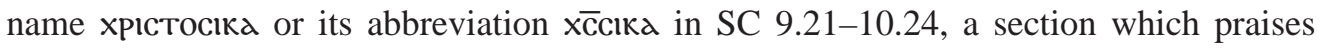
the characteristics of Christ in a manner that makes us call this passage a 'Credo'. In this section, however, we already encounter some exceptions. In SC 10.3, the preceding єিмmo in $е \bar{M}$ Mo $x \overline{\mathrm{C}} \mathrm{Cl}<\mathrm{Ka}>$ 'we know that Christ...' is also rubricated. This cannot be explained by an 'overshooting' of the scribe, forgetting to switch back to black after using red. He must have consciously selected the colour red to begin this particular phrase. Further on,

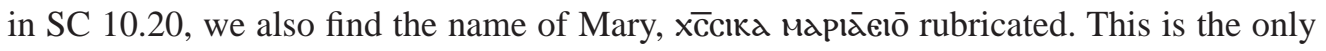
time her name occurs in SC.

Other names are seemingly inconsistently rubricated. For example, SC 4.10 ח̣ạka, 'Father' is rubricated, but SC 10.12 (in the 'Credo' section) חaח $\bar{\lambda} \lambda \lambda \lambda$ is not. It is also black

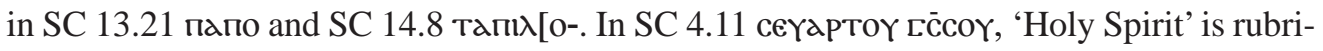

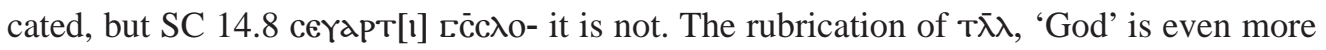
puzzling. If we look at one of the last few pages in SC, we find that in SC $22.4 \mathrm{~T} \bar{\lambda} \lambda \bar{\lambda} \lambda$ on and SC $22.18 \tau \bar{\lambda} \lambda \bar{\lambda} \lambda$ on are rubricated, while SC $22.9 \tau \bar{\lambda} \lambda \lambda[1] \Gamma \bar{\lambda} \lambda \epsilon$ and SC $22.13 \tau \bar{\lambda} \lambda \bar{\lambda}$ are black.

Following these brief observations, it appears that not all sacred names in SC are rubricated consistently, which raises the question of whether there might be another underlying motivation for the colour usage in this text. Again, if we keep in mind that these codices were highly prized devotional objects, it appears unlikely that the seemingly aberrant colour usage was merely decorative, the brainchild of a particularly frivolous scribe. So, what could be a possible explanation for this variation?

A pattern emerges once we take biblical citations into account. SC $22.4 \mathrm{~T} \bar{\lambda} \lambda \bar{\lambda} \lambda$ on is part

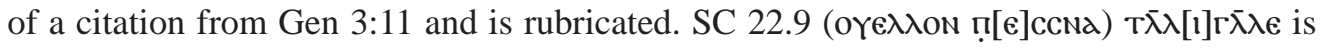

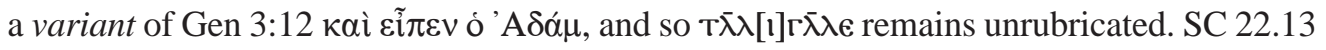
$T \bar{\lambda} \bar{\lambda} \lambda$ is part of a sentence that cannot be traced back to Genesis or another biblical text and is again written in black. SC 21.7 T $\bar{\lambda} \lambda \bar{\lambda} \lambda$ on and SC $21.16 \tau \bar{\lambda} \lambda \bar{\lambda} \lambda$ on are rubricated and part of a translation of Gen 3:9, ${ }^{21}$ whereas SC $21.14 \tau \bar{\lambda} \lambda \overline{\mathrm{N}}$, SC $21.15 \mathrm{~T} \bar{\lambda} \lambda$, and SC 21.17 $T \bar{\lambda}$ are in black and none of these are part of a biblical citation. Also, all the instances of $T \bar{\lambda} \lambda$ on SC 7-9 are in black, and none of them refer to biblical citations. ${ }^{22}$ So it appears as if sacred names that are directly found in biblical citations are rubricated, whereas those that are added by the author as a matter of elaboration or explication are not.

This pattern persists with other sacred names. SC $16.26 \times \overline{\mathrm{c}} \mathrm{cl} \overline{\mathrm{d}}$, SC $17.1 \times[\overline{\mathrm{c}} \mathrm{c}] \mathrm{k} \mathrm{d}$ and SC $17.1 \times[\overline{\mathrm{C}} \overline{\mathrm{M}}]$ all refer to Gal 3:27 and are rubricated. The same holds for SC $11.11 \overline{\mathrm{\imath}} \mathrm{cl}$

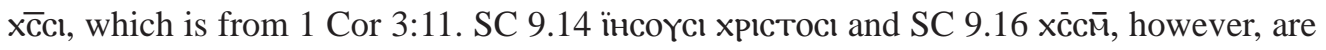
written in black, as they do not appear in a biblical citation.

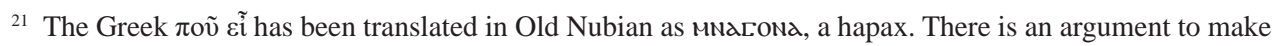
that this form is better translated as 'What have you become?' rather than 'Where are you?' but its origin as a (mis)translation of Gen 3:9 seems beyond doubt.

${ }^{22}$ Browne identifies SC 9:8 $T \bar{\lambda} \lambda \bar{N}$ as part of Jn 17:13. This is based on an incorrect reading. 
There are two segments in SC where another pattern emerges. SC 12.5-13 consists of two sentences, the first one explaining and introducing the second, which is a citation from Ps 7:12. Now in what appears to be an 'inverse' rubrication pattern, SC $12.5[\mathrm{~T} \bar{\lambda}] \lambda \bar{\lambda}$, SC 12.7 [T] inside the citation, SC $12.10 \mathrm{~T} \bar{\lambda} \lambda \lambda$ is not. A similar inverse pattern is found in SC 17.11-24. This is a meditation on Jn 1:1, which only appears at the end of the segment. Again, the

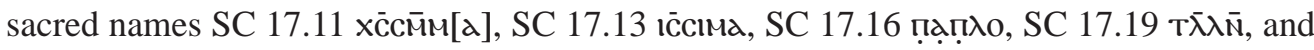
SC 17.21 [1] $\mathrm{T} \bar{\lambda} \lambda \imath \lambda \alpha \lambda o$ and SC $17.24 \mathrm{~T} \bar{\lambda} \lambda \bar{\lambda}[\lambda \mathrm{ON}]$ are not.

What both patterns of rubricating the biblical citation or its immediate elaboration share with the rubrication seen in the 'Credo' and the 'Hymn of the Cross' is a conscious attempt to 'highlight' certain rhetorically important structures in the homily. They guide the reader's eye to the most salient points in the text.

Another way of reading through the rubrications in SC is by considering how they mark the first instance of every important biblical author: SC 11.3 пєтросіг $\bar{\lambda} \epsilon$ (also part

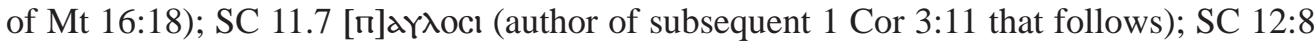
$\triangle \lambda$ \Tा (author of subsequent Ps 7:12-14); SC 17:21 [1] Note then that the second instance of Paul, SC 16.25 паץ入oc remains unrubricated; his name has already been highlighted.

There are, of course, also what appear to be exceptions or inconsistencies. For example,

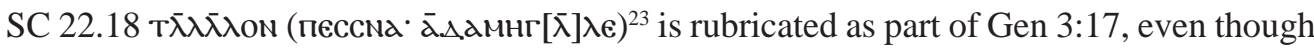
the Septuagint does not explicitly mention God: $\tau \tilde{\omega} \delta \dot{\varepsilon}$ 'A $\delta \dot{\alpha} \mu$ cĩ $\pi \varepsilon v$. Following the rendering in black of SC $22.9 \tau \bar{\top} \lambda[1] \Gamma \bar{\lambda} \lambda \epsilon$, another interpolation, we would have expected the same here. However, when taken together with first mention and (otherwise inexplicable) rubrication of the Holy Trinity in SC 4.9-11, SC 22.18 т $\bar{\lambda} \lambda \bar{\lambda} \lambda$ on and SC 24.10 x $\bar{c}$ [ [3-4], the last two occurrences of God and Jesus in the text before the colophon (which is written in a different hand), we find in fact a perfectly symmetrical rubrication marking the beginning and end of the homily: Christ-(God the) Father-Holy Spirit-God (the Father)-Christ.

Even though our analysis so far may account for most of the rubrications, and provides a framework in which to think the ways in which rhetorical emphasis was given to different elements or the text, there are still several rubrications that require an explanation:

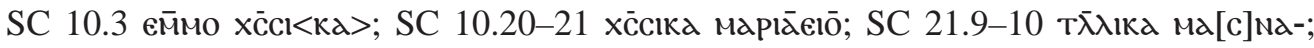
and SC 21.15 T $\bar{\lambda} \lambda \bar{\lambda} \lambda$ ow . ., ${ }^{24}$ which we can loosely translate as We know that Christ... Christ from Mary ... ignorant of God ... God [says]. Similar examples can be found in the Stauros-Text. ${ }^{25}$

Like SC, St was intended for deposition at the Jesus Church in Serra East, and contains the 'Hymn on the Cross' also featured in SC, and here we find a similarly remarkable

${ }^{23}$ The non-rubricated part of the phrase is parenthesised.

24 Browne 1984: 67 has т $\bar{\lambda} \lambda \bar{\lambda} \lambda$ п̣ẹc.

${ }^{25}$ The same holds for P. Attiri 2.i.18-19 (see: Van Gerven Oei et al. 2016: 44-45), but this case will not be analysed, because the manuscript is very fragmentarily preserved and does not provide the same picture as SC and St discussed here. 
usage of colour. As in SC, certain elements are consistently rubricated: supralinear strokes, interpunction, and the lobes of the letter $\phi$ and sometimes the o (e.g. St 11.8). Furthermore, red is used for the incipit (St 1.1-2.8) and what Griffith calls 'leading phrases' ${ }^{26}$ Browne is even less committal when he simply states: I have underlined all words that are in red ink [...]. This seems preferable to Griffith's vague statement. ${ }^{27}$ Like Griffith, however, Browne fails to analyse the specific phrases that are marked in red.

To start, all instances of the word ćtaypoc, 'cross' have been rubricated, as in the 'Hymn on the Cross' section in SC. Although there seem to be no exceptions to this in the main text, the scribe frequently seems to 'overshoot', rendering more words in red ink than appears to be strictly necessary. For example, the entire sentence in St 10.3-5 ćтдүроска

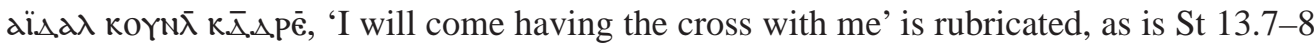

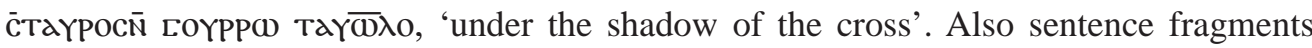
are rubricated, creating what appear to be noun phrases on top of a regular sentence. For

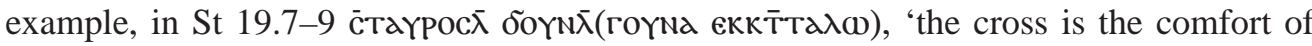
the infants', the sequence $\bar{c} \operatorname{Ta\gamma poc} \bar{\lambda}$ бoү $\mathrm{N} \bar{\lambda}$ is rubricated, rendering something like 'the pregnant cross'. Such rubrication occurs multiple times in the manuscript.

Apart from ćtaүpoc and related 'leading phrases', there are also other elements that are

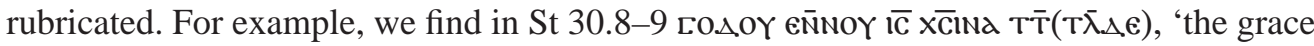

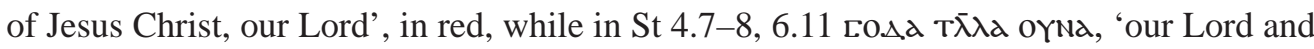
God' is in regular black ink. Also, other instances of (persons of) the Holy Trinity remain

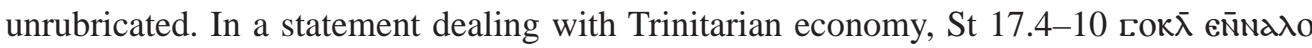

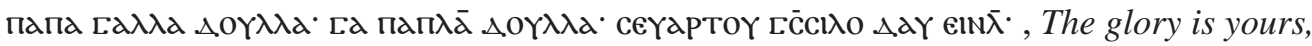
Father who is in the Son, Son who is in the Father, being together with the Holy Spirit,

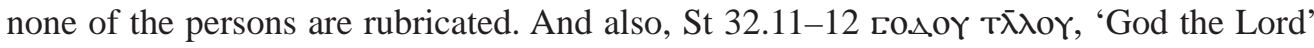
is written in black. Similar inconsistencies are found with the name of the apostle Peter. In St 4.5-6 пєтросіо is written in black, while in St 5.10 and 8.3 пєтро̄cl is red, as well as the phrase St 6.9-10 петро̄cion оүска пєс<сna>, 'Peter answered and said'. The only

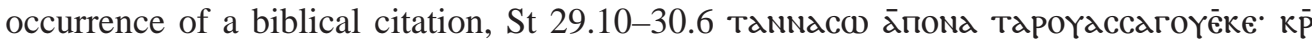

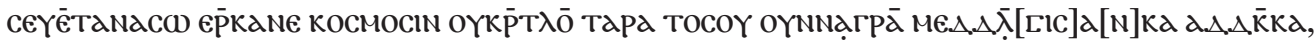
Come, you who my Father blessed, come and inherit the kingdom that they caused to be born, prepared and made ready(?) before from the foundation of the world (Mt 25:34) contains the sacred name $\bar{\lambda}$ поNd, but this is not rubricated.

If we then turn toward to the colophon (St 31.11-36.11), we find several instances of nomina sacra, such as St 35.2-3 ï̈ноү[cl] xpıctocı, 'Jesus Christ' and T $\bar{\lambda} \lambda$, 'God' passim. Unlike in the main text, none of the instances of the word ctaypoc have been rubricated,

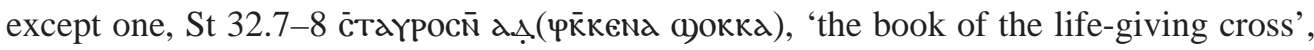
which seems to refer to the title of the work.

\footnotetext{
${ }^{26}$ Griffith 1913: 41.

27 Browne 1983: 78.
} 


\section{'POLYPHONIC' TEXTS}

Based on the above observations, the rubrication in St differs from the one in SC and is unrelated to biblical citations. Much more prominent, however, is the use of rubrication to highlight a text 'on top' of the text, a text that consists of the rubricated phrases alone. We hinted at this possibility in SC, but this technique seems fully deployed in St. Let us therefore have a closer look at the non-trivial rubrications in St, namely all rubrications in the main text that are not simply c̈таYpoc.

\section{St 5.9-10 петро̄cı, 'Peter'}

St 6.9-10 петро̄сіоn оүскג пєс< <cnd>, 'Peter answered and said'

St 8.3 пєтро̄сl, 'Peter'

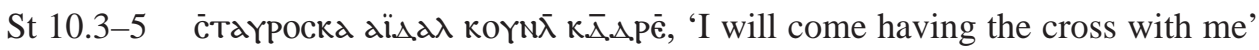

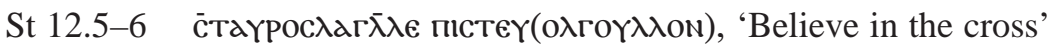

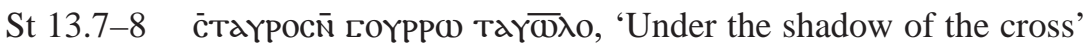

St 14.1-2 '̈таүросоү oүe ' $\lambda$ ', 'One cross'

St 15.5-6 '̄таүросоү гоккоna, 'Of the glorious cross'

St 16.2-3 '̈таүросоү гококк o(kd), 'Call the glorious cross'

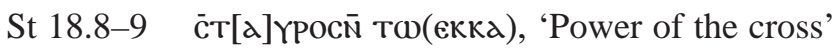

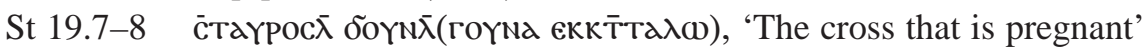

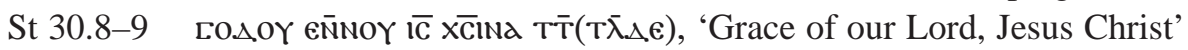

The rubricated text opens with a triple invocation of the apostle Peter, which stresses his importance in the St. The importance of Peter is a topos in the type of literature to which St belongs, namely the Pseudo-Apostolic Memoirs. According to the most authoritative analysis of these works, ${ }^{28}$ they can be divided in three parts: first, an introduction; second, a discourse where an apostle questions Christ concerning the topic of interest in the given work; and third, the commissioning of the apostles by Christ to proclaim his teaching to the whole world. Peter plays the most prominent role in the discourses of the second part of these Memoirs, ${ }^{29}$ and characteristically the title Gospel of Peter has been assigned to a manuscript fragmentarily preserved with many similarities to the contents of the St. ${ }^{30}$

Especially with regard to the rubricated phrases in St, Peter seems to have a rather structural role. So, the first rubricated phrase, St 6.9-10 пєетро̄сıо оүска пєс $<\mathrm{cNa}>$, 'Peter answered and said', suggests that the following rubricated phrases form a coherent speech that could be attributed to him. Several of the phrases are completely rubricated and form a syntactical unit. In several other cases, however, only part of the last word is rubricated. The result is a reinterpretation of grammatical relations. For example, the whole phrase

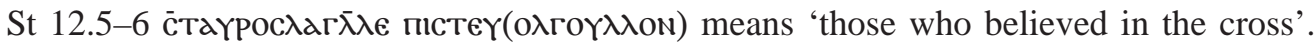

\footnotetext{
28 Suciu 2017.

29 Suciu 2017: 8.

30 Suciu 2017: 3 and n. 7; Schenke 1998.
} 
The rubricated part, however, invites the imperative interpretation 'believe in the cross' or perhaps infinitival 'to believe in the cross'. Even more dramatically, St 19.7-8 čтarpoc̄̄

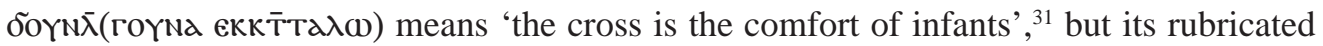
part could be rendered 'the cross that is pregnant'.

Thus, the syntactical reinterpretation that the rubrication allows strengthens the idea that we are dealing here with a deliberate attempt of the scribe to lift out a 'second' text from the primary text, a rubricated text that we would tentatively like to call the 'Prayer of Peter'. The result is a form of 'polyphony' or 'counterpoint' of the non-rubricated and rubricated text that provides a structure for the entire Stauros-Text. For the text opens with Peter asking Jesus to reveal the mysteries of the cross to the assembled apostles. This is followed by Jesus's answer (in the form of a discourse preserved in Coptic literature both from Nubia and Egypt) and the extensive 'Hymn on the Cross' (also preserved in the SC, as well as in Coptic literature). ${ }^{32}$ Thus, the 'Prayer of Peter' straddles both parts of the manuscript and provides a contrapuntal commentary that is both contained in and distinct from Jesus's speech.

These observations allow us to return to SC, and the few extended rubrications that defied our earlier interpretative attempts:

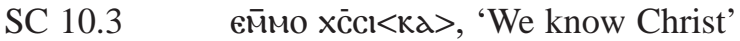

SC 10.20-21 xс̄cika mapī̄eiō, 'Christ from Mary'

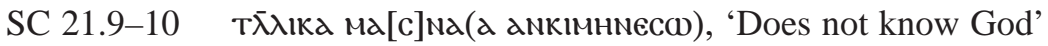

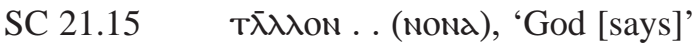

As in St, the rubrications significantly alter the syntactic relations. In SC $10.3 \times \bar{c} \overline{c l}<\mathrm{ka}>$ is actually the subject of a complement clause, but in the rubricated phrase it functions as

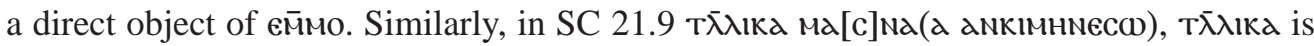
the subject of the complement clause, 'Don't think that God is ignorant/doesn't know'. However, in the rubricated phrase, it is the direct object of the verb ma[c]Na. Thus, the scribe here seems to use the same technique more extensively employed in St, bringing out a second voice in the text through rubrications of more than one word. The two crucial elements here are the mention of Mary as the one from whom the Christ was born and not knowing God.

The importance of Mary for Nubian Christianity was recognised from early on in research, ${ }^{33}$ also linked with the Christological conflicts between pro- and contra-Chalcedonians. ${ }^{34}$ With an initial focus on the evidence provided from mural paintings and in comparison with both Egyptian and Byzantine material, ${ }^{35}$ Mary's role in Christian Nubia has been variably discussed, often in connection with royal authority. ${ }^{36}$ Most recently, evidence of

\footnotetext{
31 Browne 1983: 91 translates 'The cross is the instructor of children'.

32 For the latest discussion, see: Suciu 2017.

33 Müller 1978: 213-214.

34 Van Moorsel 1970.

35 Scholz 2001: 225-228.

36 Zielińska 2014: 946-948; Van Gerven Oei 2017.
} 
a special role in the funerary cult has been identified as linking with Ethiopian traditions as well. ${ }^{37}$ However, in SC 9.21-10.23, the discussion is about what the homilist and his congregation know about Christ through a series of aphorisms creating an image of their Christological beliefs. Against this context, the reference to the birth from Mary is used in

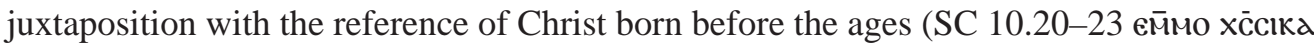

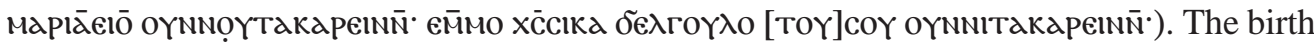
from Mary is a reference to Christ's humanity, which remains nevertheless undivided from

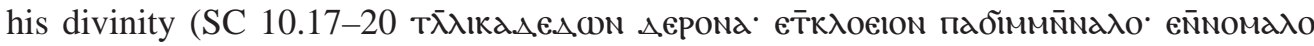

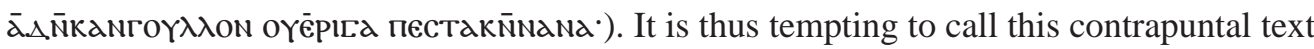
a 'Mariological Credo'.

The question that arises is whether the other two rubricated phrases are related to this 'Mariological Credo'. This is difficult to ascertain, but if this were the case then the absence of knowledge about God might imply either that the Mariological belief shows 'ignorance of God' and therefore we should understand that the copyist responsible for the rubrications takes distance from these beliefs; or that indeed the birth from Mary did not know God (in the biblical sense, i.e. carnal knowledge and sexual intercourse, e.g. Gen 4:1 And Adam knew Eve his wife; and she conceived) and was thus unrelated to divinity. In the latter case, the copyist not only endorses the general Christological overtone of the pseudo-Chrysostomian homily but even underlines through the rubrications that God says (SC 21.15) this: We know Christ (SC 10.3), Christ born from Mary (SC 10.20-21) without knowing God (SC 21.9-10). This hypothesis should remain an open question, perhaps to be elucidated by future discoveries that will throw new light on the scribal practices examined here, their meanings, and their implications.

\section{CONCLUSION}

Our analysis of two Old Nubian texts, the pseudo-Chrysostomian homily Sermon on the venerable Cross and the Stauros-Text, both destined for deposition at the Jesus Church at Serra East, has shown that both manuscripts feature rubrication patterns of particular interest. These rubrication patterns serve as a rhetorical device to highlight prominent figures and passages, such as biblical citations. The rubrication found in both texts also appears to serve the creation of secondary texts or 'voices' within the main text, creating what we call a 'polyphonic' text.

It is in itself remarkable that this usage of rubrication is found in two texts that can be precisely located at the same site. This perhaps indicates the presence of a manuscript tradition associated with the Jesus Church in Serra East, the 'Hymn on the Cross', or a combination of both. Without further evidence it is uncertain in which direction the link can be found. What we have established, or at least made plausible, is that the rubrications are not the product of mere authorial fancy or chance, and that there is number of shared characteristics, and even semantic coherence, between the rubricated phrases.

${ }^{37}$ Lajtar, Van der Vliet 2017: 260-276. 
It is impossible to know to what extent the intentionality we are ascribing to the rubrication of SC and St is grounded in the lived experience of the scribe who prepared the manuscript. The alternative, however, is to abide by referring to 'certain religious names and words' or 'leading phrases' without the chance to deepen our understanding of Nubian manuscript culture and the potential meaningfulness of every aspect of the text. Not doing so would reject out of hand valuable insights that may be gleaned from the few materials that have survived.

\section{References}

Boud'hors, A. 1997: L’onciale penchée en copte et sa survie jusqu'au XVe siècle en HauteÉgypte, [in:] Déroche, F., Richard, F. (Eds), Scribes et manuscrits du Moyen-Orient, Paris, 117-133

Browne, G.M. 1983: Griffith’s Stauros-Text, StudPap 22, 75-119

Browne, G.M. 1984: Chrysostomus Nubianus: An Old Nubian Version of Ps. Chrysostom, In venerabilem crucem sermo, PapCastr 10, Rome

Browne, G.M. 1996: Old Nubian Dictionary, CSCO 556, Subsidia 90, Leuven

Browne, G.M. 2002: Old Nubian Grammar, Languages of the World. Materials 330, Munich DBMNT: www.dbmnt.uw.edu.pl (accessed May 15, 2018)

Gerven Oei, V.W.J. van 2017: A Dance for a Princess: The Legends on a Painting in Room 5 of the Southwest Annex of the Monastery on Kom H in Dongola, JJP XLVII, 117-135

Gerven Oei, V.W.J. van, Laisney, V.P.-M., Ruffini, G., Tsakos, A., Weber-Thum, K., Weschenfelder, P. 2016: The Old Nubian Texts of Attiri, Dotawo Monograph 1, Earth

Gerven Oei, V.W.J. van, Łajtar, A. 2019: Two Old Nubian Inscriptions from Akasha West, EtudTrav XXXII, 89-97

Gerven Oei, V.W.J. van, Tsakos, A. forthcoming: Translating Greek to Old Nubian: Reading between the Lines of Ps.-Chrysostom's In venerabilem crucem sermo, [in:] Batovici, D., Toca, M. (Eds), Caught in Translation: Studies on Versions of Late-Antique Christian Literature, Texts and Studies in Eastern Christianity 17, Leiden, 204-240

Gilhus, I.S., Tsakos, A., Wright, M.C. (Eds) 2019: The Archangel Michael in Africa: History, Cult and Person, London

Griffith, F.Ll. 1913: The Nubian Texts of the Christian Period, Abhandlungen der Königlich Preussischen Akademie der Wissenschaften, philosophisch-historische Klasse 8, Berlin

Hubai, P. 2009: Koptische Apokryphen aus Nubien. Der Kasr el-Wizz Kodex, Texte und Untersuchungen zur Geschichte der altchristlichen Literatur 163, Berlin

Łajtar, A., Vliet, J. van der 2017: Empowering the Dead in Christian Nubia. The Texts from a Medieval Funerary Complex in Dongola, JJP-Suppl. XXXII, Warsaw

Moorsel, P.P.V. van 1970: Die stillende Gottesmutter und die Monophysiten, [in:] Dinkler, E. (Ed.), Kunst und Geschichte Nubiens in Christlicher Zeit, Recklinghausen, 281-290 
Müller, C.D.G. 1978: Grundzüge der Frömmigkeit in der nubischen Kirche, [in:] Leclant, J., Vercoutter, J. (Eds), Études Nubiennes : Colloque de Chantilly, 2-6 juillet 1975, BiEtud 77, Cairo, 209-224

Ochała, G. 2014: Multilingualism in Christian Nubia: Qualitative and Quantitative Approaches, Dotawo 1, 1-50

Parkinson, R., Quirke, S. 1995: Papyrus, Austin

Russell, M. 1985: Nubia and Abyssinia: Comprehending their Civil History, Antiquities, Arts, Religion, Literature, and Natural History, London

Schäfer, H., Schmidt, K. 1906: Die ersten Bruchstücke christlicher Literatur in altnubischer Sprache, Sitzungsberichte der Königlich Preussischen Akademie der Wissenschaften 43, 774-785

Schenke, H.-M. 1998: Das sogenannte ‘Unbekannte Berliner Evangelium’(UBE), ZAC 2, 199-213

Scholz, P.O. 2001: Das nubische Christentum und seine Wandmalereien, [in:] Jakobielski, S., Scholz, P.O. (Eds), Dongola-Studien. 35 Jahre polnischer Forschungen im Zentrum des makuritischen Reiches, Bibliotheca nubica et aethiopica 7, Warsaw, 177-251

Suciu, A. 2017: The Berlin-Strasbourg Apocryphon. A Coptic Apostolic Memoir, WUNT 370, Tübingen

Tsakos, A. 2016: A Paleographic Detail from Nubian Manuscripts: The Decoration of the Lobes of the Letter «Ф» with Red Ink, [in:] Henderson, W., Zacharopoulou, E. (Eds), Greece, Rome, Byzantium and Africa: Studies Presented to Benjamin Hendrickx on his seventy-fifth Birthday, Athens, 637-652

Tsakos, A. forthcoming: The Textual Finds, [in:] Obłuski, A. (Ed.), Excavations at Qasr el-Wizz, Oriental Institute Nubian Expedition XV, Chicago

Woźniak, M.M. 2018: Costume and Identity: The Miniature of Ms. Or. Quart. 1020 (Berlin, Staatsbibliothek), [in:] Honegger, M. (Ed.), Nubian Archaeology in the XXIst Century: Proceedings of the Thirteenth International Conference for Nubian Studies, Neuchâtel, 1st-6th September 2014, OLA 273, Leuven, 625-630

Zielińska, D. 2014: The Iconography of Power - The Power of Iconography: The Nubian Royal Ideology and Its Expression in Wall Painting, [in:] Anderson, J.R., Welsby, D.A. (Eds), The Fourth Cataract and Beyond: Proceedings of the 12th International Conference for Nubian Studies, British Museum Publications on Egypt and Sudan 1, Leuven, 943-949 


\section{ÉTUDES et TRAVAUX XXXII / 2019}

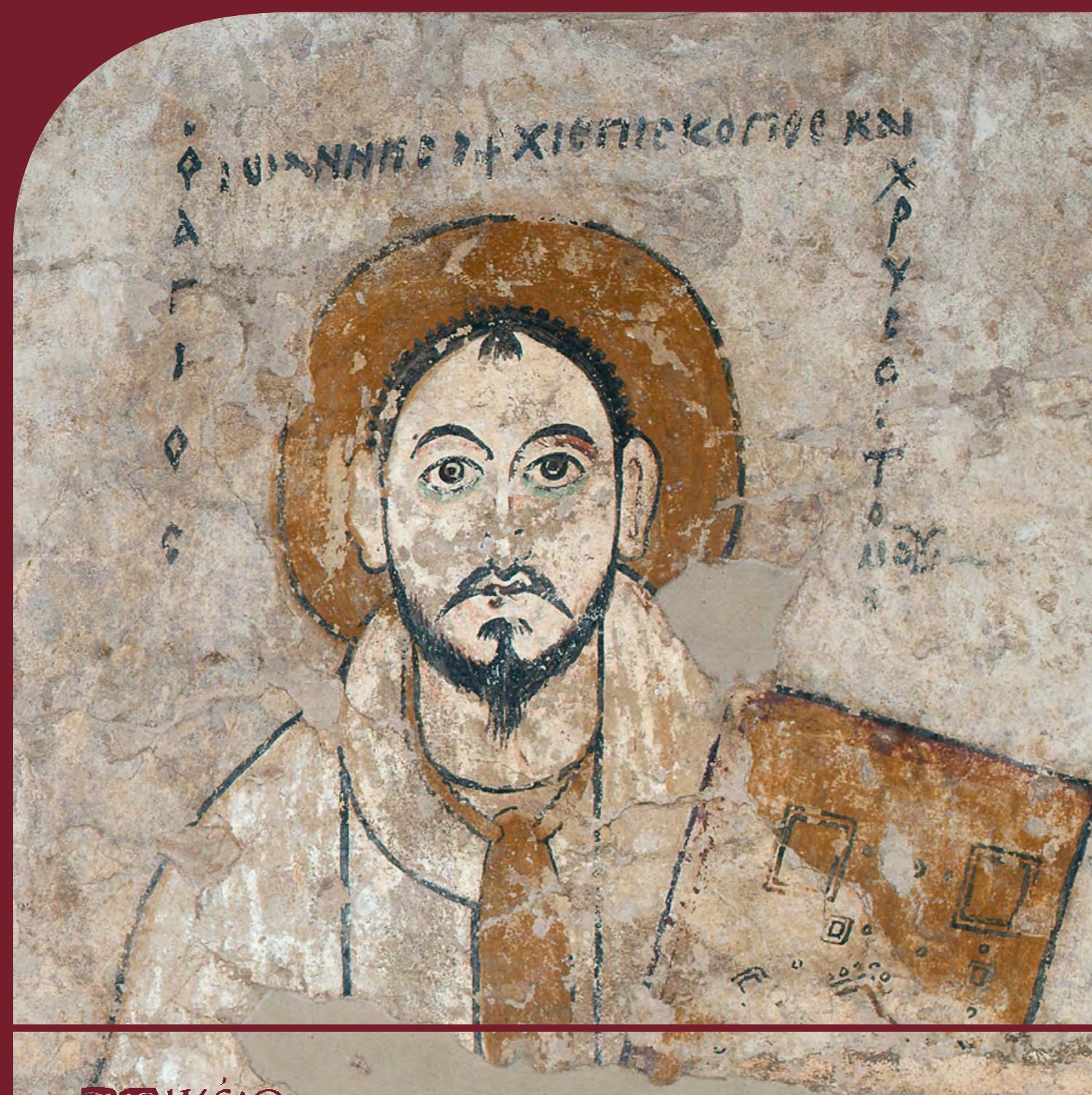

BOMIKSiO Institut des Cultures Méditerranéennes et Orientales ED2A PAN de l'Acácémie Polonaise des Sciences 


\title{
COMITÉ DE RÉDACTION SCIENTIFIQUE
}

Maciej Makowski - rédacteur en chef Jadwiga Iwaszczuk - rédacteur

Maciej G. Witkowski - rédacteur

Agnieszka Ryś - sécretaire de la rédaction

Bogdan Żurawski - rédacteur thématique du volume

CONSEIL SCIENTIFIQUE DU JOURNAL

M. Kobusiewicz (IAE PAN, Warszawa), E. Laskowska-Kusztal (IMOC PAS, Warszawa),

D. Michaelides (University of Cyprus, Nicosia),

J.Ch. Moretti (IRAA-MOM, Université de Lyon 2/CNRS),

D. Raue (Ägyptisches Museum der Universität Leipzig), P. Reynolds (ICREA, España),

D. Welsby (British Museum, London)

\section{COMITÉ SCIENTIFIQUE DE LECTURE}

D.E. Arnold (Wheaton College/The Field Museum, Chicago), H.D. Baker (University of Toronto),

P. Ballet (ArScAn-ESPRI, Université Paris Nanterre), Ch. Barber (Princeton University),

N. Beaux-Grimal (IFAO, Caire/Collège de France, Paris), A. Boud'hors (CNRS, IRHT, Paris),

J. Budka (Ludwig-Maximilians-Universität München), R. David (SFDAS),

A. Delattre (CPEG, Bruxelles), A. Dodson (University of Bristol),

E. Fogliadini (Facoltà Teologica dell'Italia Settentrionale, Milan),

V. Francigny (CNRS/CRES, Paris), L. Gabolde (CNRS), C. Gobeil (Egypt Exploration Society, London),

N. Hamdi (UCL, Louvain), J. den Heijer (CIOL/INCAL, Louvain-la-Neuve),

S. Ikram (American University in Cairo), Ch. Leitz (Universität Tübingen), S. Ortisi (Universität München),

E. Rova (Università Ca' Foscari Venezia), G. Ruffini (Fairfield University),

A. Sasson (San Diego Natural History Museum), H. Satzinger (Universität Wien),

S.M. Schellinger (The Ohio State University, Columbus), G. Schreiber (Eötvös Loránd University, Budapest),

E. Teeter (University of Chicago), S. Torallas-Tovar (University of Chicago),

Y. Tristant (Macquarie University, Sydney), V. Vaelske (independent researcher),

H. Vymazalová (Charles University, Prague), P. Weschenfelder (Universität Wien),

B. Williams (University of Chicago/PCMA UW, Warszawa),

K. Winther-Jacobsen (The Danish Institute at Athens), E. Zacharopoulou (University of Johannesburg),

P. Grotowski (UPJPII, Kraków), E. Papuci-Władyka, J. Śliwa (IA JU, Kraków), A. Ćwiek (IA AMU, Poznań),

K.O. Kuraszkiewicz, M. Pinker (FOS UW, Warszawa), Ł. Niesiołowski-Spanò (IH UW, Warszawa),

M. Gawlikowski, Mahmoud El-Tayeb (PCMA UW, Warszawa), S. Rzepka (IA UW, Warszawa)

\author{
RÉDACTION TECHNIQUE \\ Monika Wesołowska
}

REVUE DES TEXTES ANGLAIS

Jo Harper 
ÉTUDES et TRAVAUX

XXXII 
INSTYTUT KULTUR ŚRÓDZIEMNOMORSKICH I ORIENTALNYCH POLSKIEJ AKADEMII NAUK

\title{
STUDIA i PRACE
}

\author{
XXXII
}

gू IKŚiO

ESAN

WARSZAWA

2019 
INSTITUT DES CULTURES MÉDITERRANÉENNES ET ORIENTALES DE L’ACADÉMIE POLONAISE DES SCIENCES

\section{ÉTUDES et TRAVAUX}

XXXII

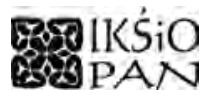

VARSOVIE

2019 
Publication scientifique financée dans le cadre du programme du Ministre de la Science et de l’Éducation Supérieure

« Programme National de Développement de l’Humanistique » pour les années 2016-2021 (projet no $3 b H 150099$ 83)

\title{
TI NARODOWY PROGRAM ROZWOJU HUMANISTYKI
}

\author{
Copyright $(\mathbb{C}$ \\ Instytut Kultur Śródziemnomorskich i Orientalnych PAN \\ et les Auteurs \\ Warszawa 2019
}

\begin{abstract}
ISSN 2084-6762
(avant 2011 : 0079-3566)

e-ISSN 2449-9579

Version première en papier, imprimée en Pologne - 150 copies

Version électronique accessible sur

http://www.etudesettravaux.iksiopan.pl
\end{abstract}

Édition: Polskie Towarzystwo Historyczne et Wydawnictwo Neriton, Warszawa

Conception générale de couverture : J. Iwaszczuk

Photo de couverture : P. Ligier ; courtoisie du Musée National de Varsovie

(Saint Jean Chrysostome, peinture, cathédrale de Faras). 


\section{Table des matières}

Editorial: Quid novi ex Nubia (par Bogdan Żurawski) ............................................... 7

Bibliography of Professor Stefan Jakobielski ................................................................ 13

Aneta Cedro, Bogdan Żurawski

Living with the Past in Modern Sudanese Village. Traditional Pottery Production

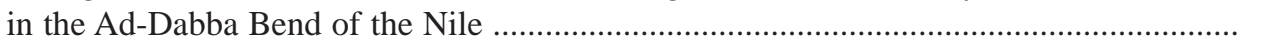

DAVID N. EDWARDS

A Possible Monastery and the 'Upper Maqs’ at Ukma-Akasha West? ............................ 53

Vincent W.J. van GeRven OeI

An Old Nubian Curse from the Faras Cathedral ........................................................ 81

Vincent W.J. van Gerven Oei, Adam Łajtar

Two Old Nubian Inscriptions from Akasha West ........................................................ 89

Vincent W.J. van Gerven Oei, Alexandros Tsakos

Rubrication Patterns in Two Old Nubian Manuscripts from Serra East .......................... 99

KAREL C. INNEMÉE

A Man in a Vessel, Once More .................................................................................. 111

KAREL C. INNEMÉE, Dobrochna ZielińSKA

Faces of Evil in Nubian Wall-Painting - An Overview ................................................ 121

ADAM ŁAJTAR

Epitaph of Merki Found in Hambukol ....................................................................... 145

MAGDALENA ŁAPTAŚ

Attributes, Vestments, Context and Inscription in the Identification of Nubian

Paintings: Proposing the 'Multi-Layer' Image Recognition Method ............................... 161

Grzegorz Ochala

Nubica Onomastica Miscellanea I: Notes on and Corrections to Personal Names

Found in Inscriptions from Faras 


\section{Robin SEIGNOBOS}

L'influence du Kitāb ahbār al-Nūba d'Ibn Sulaym al-Uswānī sur l'Histoire des églises et monastères d'Égypte d'Abū al-Makārim

JACQUES VAN DER VLIET

Exit Bishop Tamer - the Sequel. A New Edition of the Epitaph of Papsine alias Doulista (DBMNT 78) 